FINANCIAL: Jurnal Akuntansi

Published by Program Studi Akuntansi STIE Sultan Agung Volume 6-Nomor 2, Desember 2020, (HIm 117-132)

ISSN-P: 2502-4574, ISSN-E: 2686-2581

Available online at: https://financial.ac.id/index.php/financial

\title{
AN OVERVIEW OF THE PERSPECTIVE OF THE DRAGONFLY \\ EFFECT IN THE IMPLEMENTATION OF CORPORATE \\ SOCIAL RESPONSIBILITY IN DIGITAL MEDIA \\ (CASE STUDY OF PT TIP TOP SUPERMARKET'S CSR PROGRAM)
}

\author{
Raden Mas Try Ananto Djoko Wicaksono ${ }^{1), 2)}$ \\ ${ }^{1}$ Program Studi Hukum Bisnis, Universitas Gadjah Mada, Kompleks Bulaksumur Blok D No. 5 \\ Caturtunggal, Depok, Sleman, Yogyakarta, 55281, Indonesia \\ ${ }^{2}$ Program Studi Pemerintahan dan Kebijakan Publik, School of Government \& Public Policy (SGPP), \\ Jalan Anyar, Citeureup Sentul - Bogor, Jawa Barat, 16810, Indonesia \\ E-mail: tryananto.wicaksono@gmail.com
}

\begin{abstract}
The aim of the research is to analyze the application of corporate social responsibility on social media in PT Tip Top. The usage of social media in corporate social responsibility activities allows the creation of an interactive dialogue that is horizontal between the company and stakeholders. The research uses qualitative research methods with a case study approach. The author uses research design 'holistic single case'. This research uses three sources of evidence including direct observation, document analysis, and literature review. This research indicates that the CSR program on online media at PT Tip Top leads to the concept of corporate social marketing.

Keywords: corporate social responsibility; implementation corporate social responsibility; social media; digital media
\end{abstract}




\section{INTRODUCTION}

Corporate Social Responsibility (CSR), which cannot be defined in a single way, nor has its concept remained unchanged since its appearance in the business world. CSR into business strategy not only responds to commitments to social agents but also analyzes its possible positive effect on financial performance indicators, due to improved employees motivation, the ability to attract talent, improved resource management, competitiveness or reliability in the company, among other aspects (Kao et al., 2018).

There are three keys of CSR in most definitions are economic, social, and environmental (Chowdhury et al., 2019; Marí Farinós, 2017; Uribe-Macías et al., 2017). First, The economic key is CSR represents the way in which companies contribute to the demands and requirements of stakeholders and especially, the role they play in ensuring long-term sustainability (FernándezGuadaño \& Sarria-Pedroza, 2018).

The social key is related to human resources (Lu et al., 2019), both those who are part of the company and those who are in its environment (Marí Farinós, 2017). The company's responsibility towards employees and society, in general, is contemplated in the social dimension of CSR (Shnayder \& Van Rijnsoever, 2018).

The environmental key referred to the obligation of companies to take care of the environment, understanding the fundamental role it plays in obtaining sustainable development and taking into account the effects that it may have on climate change (Lu et al., 2019; Marí Farinós, 2017; Taliento et al., 2019).
Previously, A lot of literature found relationships between the company's social, environmental, and financial and economic performance (Brogi \& Lagasio, 2019; Chowdhury et al., 2019; Taliento et al., 2019), concluding that the three keys are interconnected, and joint action ensures long-term sustainability.

The actual condition of retail companies in Indonesia also places the issue of CSR as something important to note. This is based on the company's sense of responsibility towards the community to contribute to empowering and providing benefits.

Utilization of surrounding public facilities carried out by the retail industry, which will automatically impact environmental conditions on the community. This condition makes the relationship between the company and the community in the end not only oriented towards financial profit, but corporate social responsibility to the community is also the focus of the company in carrying out its business activities.

In line with the definition of The World Business Council for Sustainable Development, defining CSR as a business commitment to contribute to sustainable economic development, working with company employees, the families of these employees, as well as the local community (local) and society as a whole to improve the quality of life (Rahman, 2009).

One of the new applications of the CSR program is to combine CSR programs and digital media. Digital media has the potential to drive social change. Asep Syamsul M. Romli in the book Online Journalism: Guidelines for Managing Digital media (2012) defines digital media as follows, "Mass media 
presented online on internet websites" (Romli, 2012). Besides, one of the forms of digital media is social media that have changed the way people interact with each other or even with companies (Hanna et al., 2011; Kietzmann et al., 2011).

CSR is benefitted by digitalization in several ways, including marketing CSR activity that benefits a lot, in addition, too (1) Societal involvement; (2) Gaining trust by evidence-based decision (3) Positive image; (4) Higher competitiveness; (5) Customer retention and wider support (Vishwakarma, 2019).

The rise of Web 2.0 has enabled consumers to actively act and react on what companies are doing, without being dependent on third parties for mediaaccess including anyone with a smartphone can potentially reach a worldwide audience (Cormode \& Krishnamurthy, 2008; O'Reilly, 2007). Furthermore, the consumers also have shifted their information-seeking behavior with regard to products and services from offline sources to electronic word-ofmouth sources (eWOM), such as social networking and review sites (Gruen et al., 2006).

The potential of digital media to make changes greater social activities inspire companies to develop CSR programs based on digital media in Indonesia. The involvement of digital media in CSR activities will revolutionize the way of communicating between companies and stakeholders, especially in more responsible corporate business activities.

Most recently, PT Tip Top Supermarket is a company that carries out digital media-based CSR activities. The CSR concept carried out by PT Tip Top
Supermarket is still relatively new in the application of the CSR program in Indonesia. This sharia company holds a CSR program called "Belajar Sains dirumah Aja" and "Hafalan Doa Harian". "Belajar Sains dirumah Aja" program aims to provide insights especially for children aged 6-12 years about science and encourage children's interest in learning science through digital media named Zoom. On the other hand, "Hafalan Doa Harian" program aims to provide insights especially for children aged 2-6 years about religious and encourage children's interest in learning Islam through social media (Instagram).

The difference between PT Tip Top Supermarket in carrying out its CSR activities from other companies has attracted the attention of the author to find out more about the CSR activities of PT Tip Top Supermarket which are applied in the implementation of the program in the realm of digital media (Zoom and Instagram). The discussion will later explain the understanding of CSR from a communication perspective.

The Selection of PT. The Tip Top Supermarket to conduct this single case study is based on several specific considerations. The first consideration is the element of affordability of the research location by the researcher, both in terms of budget and time efficiency. The implementation of the study in the selected location did not cause problems in terms of the ability of the data. One thing that is very helpful in researching this preferred location is the issue of budget. The author are not required to pay higher costs for field studies when compared to research elsewhere. Besides, the selection of this research location can provide time 
efficiency and can still carry out the main duties of the author as an employee of the company.

The author will emphasize the application of PT Tip Top Supermarket's CSR program through the Belajar Sains dirumah Aja" and "Hafalan Doa Harian" program starting from the planning, implementation, and evaluation processes. At the end of the discussion, the author will explain the concept of CSR with a new concept, namely corporate social responsibility in digital media. These factors make this research have more value than other existing studies.

In elaborate to understand the foundation strategy of the Tip Top Supermarket's CSR program, Smith and Aaker (2010) use the analogy of the dragonfly's four wings. the four wings are: focus on a single goal, grab attention, engage people in a cause and empower them to take action. When the companies have all the wings of the dragonfly working in concert with one another, it creates a ripple effect that will connect with people in a way that makes people will feel empowered to participate, cocreate, and engage. (Aaker et al., 2010)

\section{THEORETICAL FRAMEWORK}

The article uses the concept of corporate social responsibility in digital media and the dragonfly model. In late 1997, The Institute of Public Relations Research and Education public relations and communications leaders gathered to ask them to demonstrate a number of technology-driven changes and the real and potential impact of changes in the way organizations communicate (Solihin, 2008).
Following are a number of illustrations regarding the impact of this new media technology: (1) The intranet and the Internet make possible two-way communication that was never possible; (2) The new media landscape is changing rapidly and will continue for the next several years; (3) Technology is able to distribute and obtain more data and information than before.

With the increasing accessibility of the Internet, especially online media such as Zoom, then it has an impact on changing the way people interact with one another. Digital media is specialized in the speed and interactivity of the communication that occurs.

The dragonfly model will be the basis for this research. The author chose the dragonfly model because this theory illustrates the power of social media to drive social change. This model can be applied with a social media-based corporate social responsibility program that aims to create change, which is in accordance with the topic under study. According to Aaker and Smith (2010), formulated the four wings of "the dragonfly model" as a guide for developing a corporate social responsibility program.

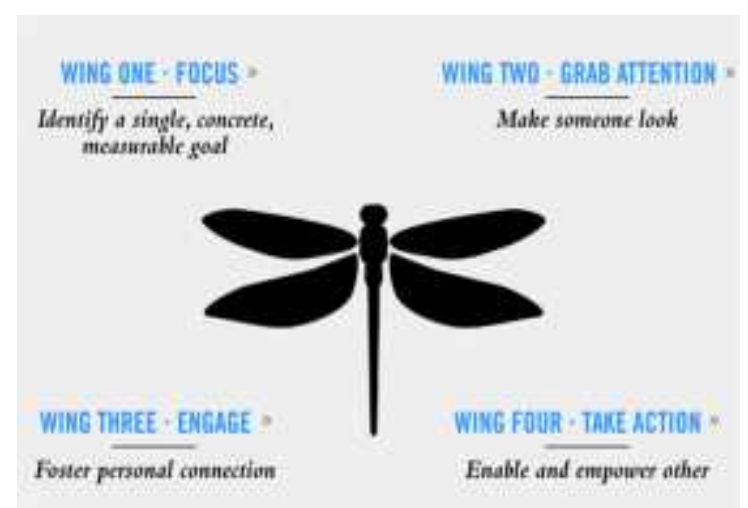

Figure 1. The Dragonfly Effect Source: (Aaker et al., 2010) 
First, Focus. In developing CSR campaigns through social media, what must be considered is to develop focused goals. In this stage, four things must be considered, including the process of determining participants, the process of determining short-term and long-term goals, and researching the program that will be held first.

Second, Grab Attention, this stage, the company will try to grab attention by empathizing with the target participants. You do this by making an interesting program. Several aspects need to be considered, including the message conveyed is personal, unpredictable, visualized to be more attractive, and involves all senses, which means the message conveyed can be seen, heard, and felt.

Third, Engage, this stage is about empowering participants to care about the campaign being delivered. You do this by making personal connections, empathizing, presenting genuine messages, and adding stories. Stories are packaged attractively and then uploaded via videos and blogs. The story will later become more meaningful because the participants and even the whole world will enjoy it.

Fourth, Take Action, this stage serves to activate and empower the community to take action. In the process of taking action, the company must help participants to be involved in the CSR program. The involvement of participants in CSR actions is one of the achievements of the CSR program.

The justification for the author to use the concept of the dragonfly effects because social media not only brings distance and time but also has the potential to drive social change. At least, that is what Aaker and Smith (2010) stated in the book The Dragonfly Effect. They said that with proper handling, social media can encourage the expected social change. The dragonfly wing framework offered by Aaker and Smith can be used as a guide in developing social media-based CSR programs in Indonesia. Several tips can be used as guidelines in developing social media-based CSR programs.

\section{METHODOLOGY}

The method used is a descriptive qualitative research method with a case study approach. Case study data can be obtained from all parties concerned, in other words, in this study; it is collected from various sources (Nawawi, 2003). Case studies make it possible to investigate a particular event, situation, or social condition and to provide insight into the processes that explain how certain events or situations occur (Hodgetts \& Stolte, 2012). Furthermore, Hodgetts \& Stolte (2012) explain that individual, group; community case studies help to show important things of concern, the social processes of society in concrete events, stakeholder experiences. Case study data can be obtained from all parties in charge, in other words, the data in this study were collected from various sources according to Stake (1995), including:

Direct observations are carried out during field visits during the case study and are more reliable if carried out by more than one person. Participant observation can be done to make researchers actively involved.

Data collection can be obtained from source documents, which will be analyzed later. Documents come from companies 
such as annual reports, official websites, and social media of PT. Top Tip.

A literature review can be carried out using some literature related to the implementation of online media-based CSR programs. To support research, library data was also collected, such as books, electronic books, journals, online journals, online archives, magazines, and others (Stake, 1995).

In short, case studies enable researchers to sustain real-life events, such as a person's life cycle, organizational and managerial processes, and changes in the social environment, international relations, and industrial maturity. The author uses time series analysis by entering the patterns from the dragonfly model according to Aaker and Smith designed four wings, among them focus, grab attention, engage, and take action. The four wings are the theoretical basis for analyzing the data in this study.

\section{RESULT}

The four dragonfly wings in the dragonfly model, PT Tip Top's marketing communication team has done almost all the wings offered, including the first wing: focus, second wing: grab attention, third wing: engage, and the fourth wing: take action. However, it is undeniable that there are still several stages that have not been maximally carried out by the marketing communication team of PT Tip Top Supermarket, including:

Focus: Testable - At this stage, it is better if the marketing communication team does more in-depth research, not only focusing on analyzing brand sponsorship promotions in digital media. But also, research on what the community needs so that the implementation of the CSR Copyright (C) 2020, FINANCIAL: Jurnal Akuntansi program will better adjust to the needs of the community as the audience.

Grab Attention: Deliver the unexpected - The messages conveyed in the CSR program are still less surprising. This can be a concern for the marketing communication team in the future.

Visualize your message - need to make promotional programs more attractive. This is so that participants are more interested in the visualization of messages displayed on social media. And in the end, get involved and take real action to make social change through inspiration through the CSR program.

Make a visceral connection - need to add a video to make the message easier to digest. Because by giving more videos will stimulate all senses of the participants, so participants will more easily accept the process of interpreting messages. Finalists for program "A" can download their profile and activities in video form.

In the concept of corporate social marketing, a company will select one or several issues that are usually related to issues that are developing in society. According to Kotler and Nancy Lee, there are several issues that are often the focus of attention to incorporate social marketing, including health issues, the environment, and community development issues (Kotler \& Lee, 2004).

The first indication, digital mediabased CSR has the aim of attracting the focus of participants to do what the company wants with the consideration of equal attention to issues as defined by corporate social marketing. This type of CSR will help companies to disseminate the program's message to the public, one of which is through social media as a media campaign. Besides, participants will 
increasingly visit PT Tip Top's social media accounts. This then has an impact on increasing the company's brand awareness. Furthermore, certain segments of the participants will then purchase the company's products with the consideration of the same concerns on the issues presented. This will make the company find that its products are sold more, and also get a positive image as a company that cares about social issues.

The second indication, the authors that marketing communication division carries out the implementation of the CSR program in order to providing positive communication to the public. This positive communication will ultimately aim to improve the company's image and lead to a succession of purchases and complete engagement. This is reversed with the concept of a CSR program that aims to provide social change to society due to the presence of companies in the community. There are aspects of social responsibility that the company carries.

According to Chris Fill and Barbara Jamieson in the book of Marketing Communications Theory and Practice, Effective communication is critically important to organizations, which is why they use a variety of promotional tools. Increasingly digital media, and the Internet, in particular, are used to 'talk' to and with their customers, potential customers, suppliers, financiers, distributors, communities, and employees, among others. Marketing communications provides the means by which brands and organizations are presented to their audiences. The goal is to stimulate a dialogue that will, ideally, lead to a succession of purchases and complete engagement (Fill \& Jamieson, 2011).
The third indication, the authors see from the pre-implementation research process of CSR programs. The marketing communication team researched by analyzing sponsor brands' engagement on the audience rather than the research process for a CSR program concept that considers what the audience needed. The concept of CSR program research should look at conditions that occur in the community, not seeing the actual conditions of the company. PT Tip Top should be able to see the problems that often arise in people's lives.

The last indication, the authors found in the indicators of program success. PT Tip Top determines the indicators of the success of the CSR program, namely increasing the number of followers on social media accounts and visits to the company website. When compared with the indicators of the supposed success of the CSR program, of course, what is the indicator of the success of the CSR program in companies is very different. It would be better if the indicators of the success of the CSR program were seen from the extent to which the community receiving the program could experience the program.

\section{DISCUSSION}

Aeker and Smith's dragonfly model formulated formula for the four wings of a dragonfly in utilizing social media for social change, including CSR programs. The formula is the focus, grab attention, engage, and take action. An overview of the perspective of the dragonfly effect by PT Tip Top's corporate communications related to the implementation of the "Belajar Sains dirumah Aja" and "Hafalan Doa Harian” program, including: 


\section{Focus}

According to Riza Primahendra on Corporate Social Responsibility Seminar entitiled "The Secret of CSR: Concept and Application in Business, stated that Corporate Social Responsibility's definition is the responsibility of an organization for the impacts of its decision and activities on society and the environment, through transparent and ethical behavior that is consistent with sustainable development and the welfare of society; takes into account the expectations of stakeholders; is in compliance with applicable law and consistent with international norm of behavior, and is integrated throughout the organization (Primahendra, 2008).

The main focus of implementing the CSR program is to regulate social change or social movements to the wider community through digital media. The focus is then identified into four focus design principles in the dragonfly model, namely humanistic (focus on what participants need from program implementation), which can be followed up (formulation of short-term goals is important to achieve long-term goals of program implementation), testable (conduct research before starting the program and at any time evaluate the program), clarity (set clear objectives in implementing the program), and happiness (which is designed in advance can provide happiness and benefits for participants and also for the company (Aaker et al., 2010). Here are four focus designs for PT Tip Top's CSR "Belajar Sains dirumah Aja" and "Hafalan Doa Harian" program, including:

Humanistic - The definition of 'humanism' is not distinctly definable due Copyright (C) 2020, FINANCIAL: Jurnal Akuntansi to different cultural interpretations and various underlying philosophical standpoints. However, some of the literature such as Gavin Rae (2010) concludes: "the meaning of 'humanism' has so many shades that to analyze all of them is hardly feasible" (Rae, 2010). Whereas other approaches take an objective view of people, in essence asking about them, 'what is this person like?' humanistic psychologists' priority is understanding people's subjectivity, asking 'what is it like to be this person?' (Sammons, 2014). PT Tip Top's Marketing Communication team focuses the program on three aspects, including education, culture, and social. Three aspects are made new from the implementation of "Belajar Sains dirumah Aja" and "Hafalan Doa Harian". These program as one of efforts to understanding the customer and people's subjectivity to find out their favour. According to the Abraham Maslow's Hierarchy of Needs model in the 1940-50', one of human need is "The esteem needs"(Maslow, 1968), Tip Top as the company tried to fulfill the need for self-respect, including such feelings as confidence, competence, achievement, mastery, independence, and freedom for the entire costumer.

Actionable - The short-term goal of the "Belajar Sains dirumah Aja" CSR program is to invite the public to increase children's interest in the world of science in digital media, namely Zoom. Meanwhile, the "Hafalan Doa Harian" CSR program is to invite and inspire people to make social changes through social movements on social media, especially Instagram related to religious education. The involvement of social media in the CSR program is expected to 
be able to quickly spread echoes about social actions to many participants.

Testable - Testability define as the ability to run an experiment to test a hypothesis or theory. When designing some research, the questions being asked by the researcher must be testable or the study becomes impossible to provide an answer to the inquiry (Allen, 2017). PT Tip Top's marketing communication team conducted research by analyzing customers in stores and online media. The final result of the research shows that Internet users in Indonesia are very high, especially Instagram social media users.

Clarity - According to John E. Sawyer (1992) define the goal of clarity as "the extent to which the outcome goals and objectives of the job are clearly stated and well defined". He examines the goal clarity as it pertains to one's duties and responsibilities, job goals and objectives, relations between individual work and the objectives of the overall unit, expected work results, and aspects of work that lead to positive evaluations (Sawyer, 1992). In order produce a successful program, the team must set clear objectives. Following the company's vision, which is "Useful for many people" (Tip Top, 2020), in implementing the "Belajar Sains dirumah Aja" program the aim of the program is that the Company wants to provide added value to its existence in the community, through an idea of science education that amplifies its resonance through digital media, namely Zoom. This is an innovation from the company to continue to support education in the community even amid a pandemic. On the other hand, the implementation of the "Hafalan Doa Harian" program is in line with the company's sharia-based business foundation, so Islamic religious values are applied to this program. The importance of religious education, especially for those children at an early age is needed in order to build tolerance and respect.

Happiness - For Aristotle, happiness entails experiencing the right emotions (Thomson, 1955). As one the state of wellbeing by increasing pleasure and decreasing pain (D. Kahneman et al., 1999). Indeed, some psychologists argue that happiness involves maximizing pleasant emotions and minimizing unpleasant emotions (Diener, 1984; Kuppens et al., 2008; Oishi et al., 1999). The team ensures that the objectives of implementing the CSR program are meaningful to participants. The value that participants and society, in general, get from implementing the CSR program is an indicator of the success of the program. Thus, as far the implementation of both programs; "Belajar Sains dirumah Aja" and "Hafalan Doa Harian" has had an indirect impact on the community. The community feels the effects such as increasing public awareness of science and religion education, the culture of people to learn, and social activities such as interactions between companies through third parties (event resource persons) and gift-giving. The company is not only a facilitator in implementing the program, but also contributes directly to giving gifts to the community.

\section{Grab Attention}

The main function of the term "attention" in post-behavioristic psychology is to provide a label for some of the internal mechanisms that determine the significance of stimuli and thereby make it impossible to predict behavior by 
stimulus considerations alone (Daniel Kahneman, 1974). The grab attention stage is related to the implementation stage, namely the communication strategy carried out by PT Tip Top's marketing communication team in implementing the CSR program. The communication strategy of the "Hafalan Doa Harian" program starts from the company's vision to realize "Satisfying the hearts of the people by running an Islamic business system." The company's vision is then implemented into the "B" program implementation. Meanwhile, Program "Belajar Sains dirumah Aja" focuses more on education in society, where sciencerelated education is less desirable. Thus, the communication strategy for the "Belajar Sains dirumah Aja" program starts with the company's collaboration with Nestle on Dancow products. Through this collaboration, the public will be more interested because of the prizes for the participants. According to the dragonfly model, there are four design principles for grab attention, including:

Get personal, Personal values are define as implicitly related to choice; they guide and even drive our decisions (AskRoxi, 2014). They refer to the behaviors by which people bring in or leave out their personal selves during work role performances. William A. Khan (1990) defined personal engagement as the harnessing of organization members' selves to their work roles; in engagement, people employ and express themselves physically, cognitively and emotionally during role perfomance (Kahn, 2005). The term engagement is only occasionally used in the book by Buckingham and Coffman (1999) that was generally about leadership, as is reflected by its subtitle What the Copyright (C) 2020, FINANCIAL: Jurnal Akuntansi world's greatest managers do differently (Buckingham \& Coffman, 2003). In the implementation of the both of CSR program, PT Tip Top's corporate communication team interacted with participants more personally. The company demonstrated this by being directly involved in communicating with participants, both on social media (Instagram) (See Figure 2) and digital media (Zoom) (See Figure 3) an example of the interaction between the company and participants. With this closeness, it is hoped that participants will be motivated to participate in social action through the CSR program.

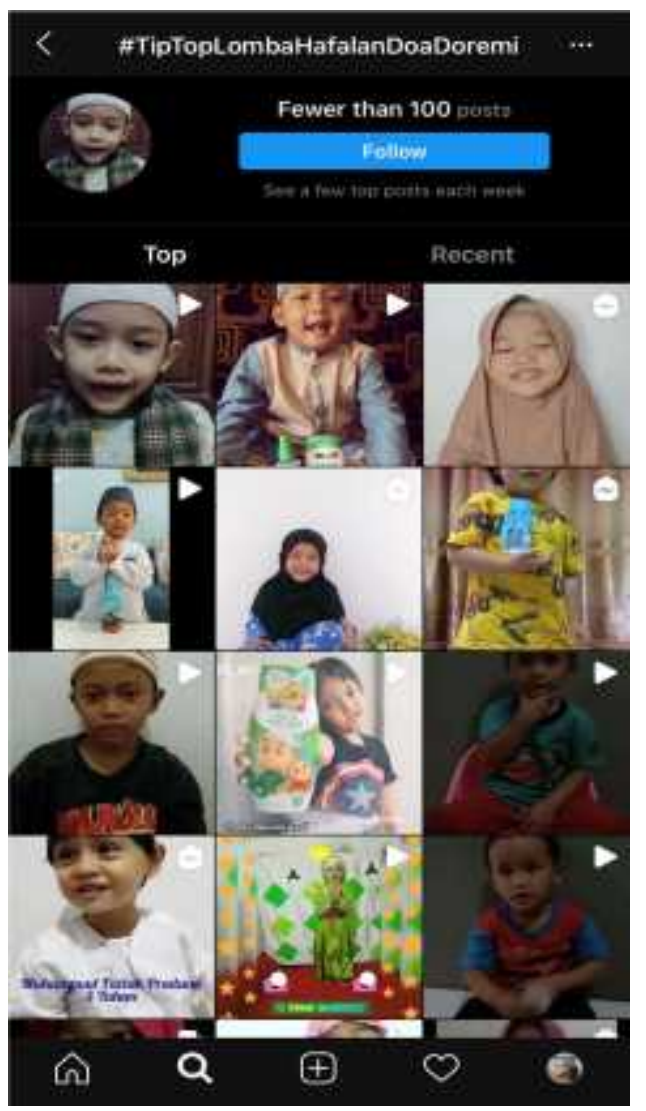

Figure 2. The Participants involvement on The Instagram, "Hafalan Doa Harian" Source: (Tip Top Supermarket, 2020) 


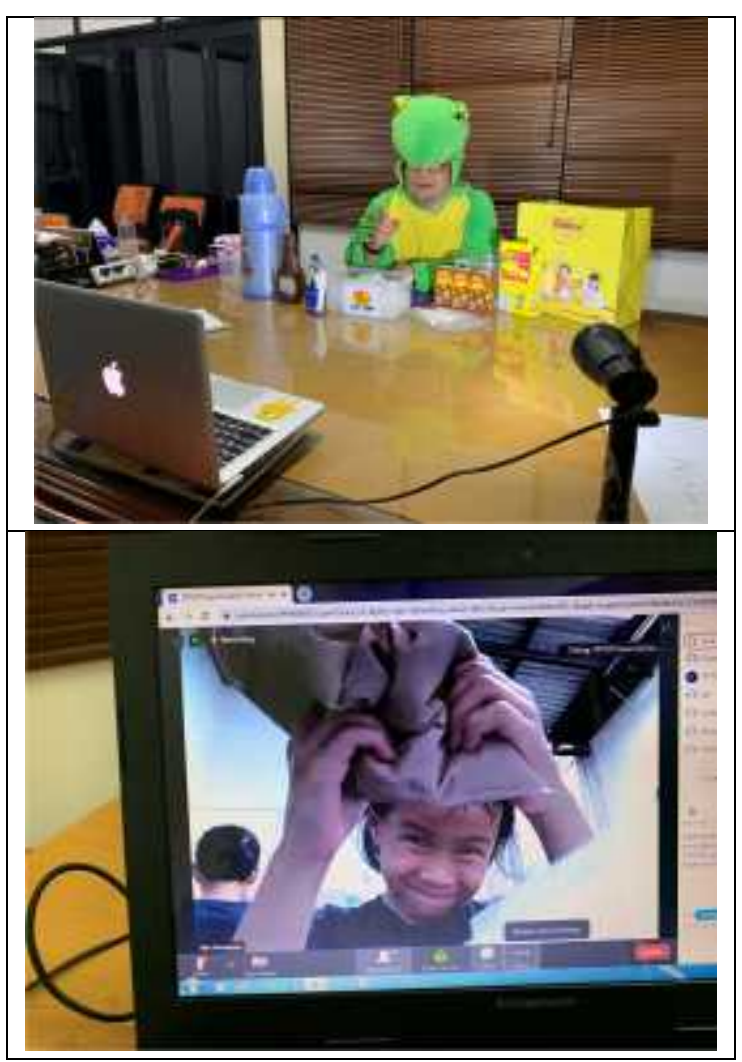

Figure 3. The Interaction with Participants on The Zoom, "Belajar Sains dirumah Aja" Program

Deliver the unexpected - The deliver the unexpected stage in the implementation of the CSR program did not run optimally. The author feels that there must be some improvements, especially in the message delivered, so that the message is packaged unexpectedly.

Visualize your message - PT Tip Top's marketing communication team uses graphic visualization in implementing CSR programs. The company considers the visualization of social media to be very important; this is as a support to increase the attractiveness of participants to the CSR program. The team with copywriters designs the text, colors, and images that are on the company's social media accounts. Here is an example of poster image visualization from the Tip Top Instagram account. (See Figure 4)
Make a visceral connection - In implementing CSR programs, the most felt is the sense of taste. The program "Hafalan Doa Harian", designed to touch the hearts of individuals to make social changes through social movements on social media. Instagram followers uploaded many videos of the participants. Their stories show happiness but not infrequently there are also touching and proud stories that invite concern.

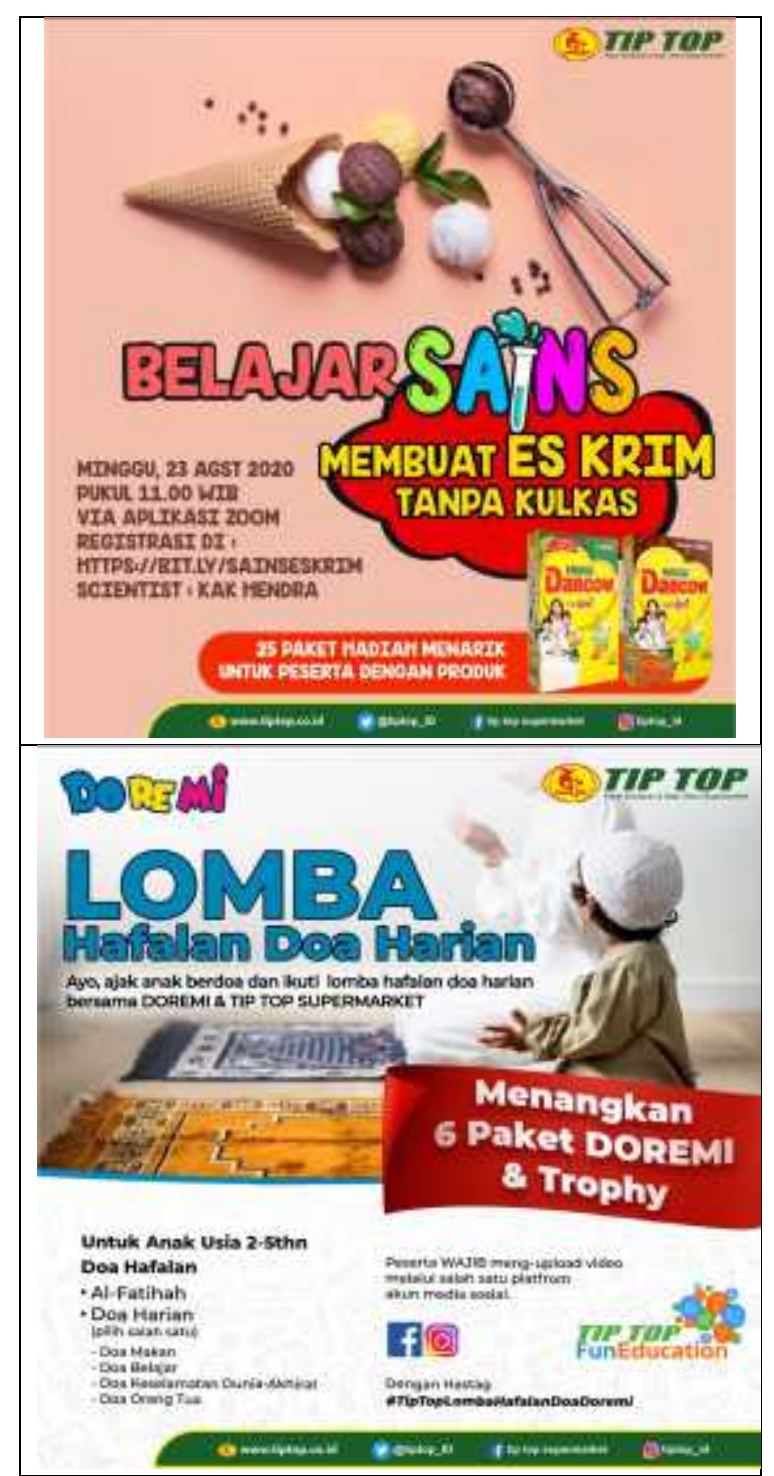

Figure 4. The Poster for "Belajar Sains dirumah Aja" and "Hafalan Doa Harian" Program on Instagram

Source: (Tip Top Supermarket, 2020) 


\section{Engage}

Engage is a process of connection between companies and participants. This is about empowering participants to care and then participate in the CSR programs that are held. This stage is often referred to as stakeholder engagement as a participant in the implementation of the corporate social responsibility program. According to Aaker and Smith, there are several principles for involving participants in CSR programs, including:

Tell a story - Through the "Belajar Sains dirumah Aja" program, PT Tip Top's marketing communication team implemented the tell a story stage. Story plots are packaged in an interesting, interactive, and participative way. In implementing the program, PT Tip Top's marketing communication team represented by the presenter named Hendra, the Founder of the Storyteller Indonesia, shared ideas or information about science experiments through digital media (Zoom) by adding stories about the idea. Meanwhile, in the implementation of the "Hafalan Doa Harian" program, PT Tip Top's marketing communication team at the tell a story stage invited participants through Instagram social media to upload videos.

Empathize - through "Hafalan Doa Harian" program, empathy as one of the values that participants can feel. The implementation of this program contains a great sense of empathy; thus, participants can easily participate in events via Instagram.

Be authentic - In the program "Hafalan Doa Harian", videos of participants were selected based on originality and creativity, their impact on society, and religious education.
Meanwhile, "Belajar Sains dirumah Aja", given innovation by educating children under 16 years through media online (Zoom) about science.

Match the media - PT Tip Top's marketing communication team combines the use of online media and offline media. Online media is applied to social media (Instagram) and digital media (Zoom). Offline media is attached to several press releases and the company's internal media. The use of these two media is a symbiotic mutualism relationship; PT Tip Top can increase the echo of social action in the realm of online media and have a profound impact on activities carried out offline.

\section{Take Action}

The take action stage will invite participants to take action or real action. Before taking action, the team carried out the grab attention and engage stages, but sometimes the participants' actions often stopped at that stage, participants were still limited to being inspired or only providing inspiration to other participants. To simplify campaign objectives, actions for social change must be made easy. According to Aaker and Smith, there are four designs in the take action wing, including:

Make it easy - The marketing communication team is well aware that CSR programs in digital media must be designed as one-click away. This is to make it easier for participants to be directly involved in social change actions on social media. In "Hafalan Doa Harian", participants are easily participated through upload the video on social media particularly Instagram. On the other hand, "Belajar Sains dirumah Aja", the participants register through an online 
form and the committee sends the online invitation through email. The event also conducted through the Zoom meeting and selects the best participants best on the creativity of the experiment result.

Make it fun - The CSR program is designed to make participants feel happy to be involved in the program. Participant involvement in the "Belajar Sains dirumah Aja" and "Hafalan Doa Harian" programs is needed creativity and innovation. PT Tip Top provides ideas and knowledge to participants by experiment entitled "making ice cream without refrigerator"; this innovation will enhance participant's knowledge about science without feeling bored upon it. Meanwhile, "Hafalan Doa Harian", as a fun way to learn Islamic religion through competition on Instagram. Through the competition, those children felt motivated to learn and understanding the Islamic value.

Tailor - In implement the CSR programs, several aspects are prioritized, namely educational, cultural, and social aspects. However, the author feels that PT Tip Top's marketing communication team has not been maximal in recording what the community needs, who are participants in the CSR program. The team is still too focused on the company's goals; this can be seen from the team's initial research in determining the application of the CSR program.

Be open - Openness in implementing CSR programs is important to reduce boundaries between companies and participants, as well as in implementing CSR programs. The openness of the CSR program is also shown by posting on the website and social media accounts of various social activities that will and have been carried out. This is to show participants about the business of companies and individuals who care about social change, trying to inspire, drive, and make social change through CSR programs

\section{CONCLUSION}

The implementation of a social media-based CSR program is a new application in CSR practices in Indonesia. There are still many aspects that need to be re-examined in relation to the true meaning of CSR programs. PT Tip Top's corporate social responsibility program tends to lead to the concept of corporate social marketing. Basically, corporate social marketing is a strategy to sell ideas to change people's thinking, attitudes, and behavior. The application of the concept of corporate social marketing in the marketing strategy is proven to empower companies to obtain support to continue their business, including in obtaining potential sources of funds from the community at large.

To concluded that the marketing communication team of PT Tip Top has not been maximally implementing the CSR program, this can be seen from the absence of all stages of the dragonfly. The author sees a number of indications that suggest that the CSR program is part of corporate social marketing. Corporate social marketing is a way in which companies support the development and implementation of behavior change campaigns intended to improve public health, safety, the environment, or community welfare. Campaigns are designed to support or influence certain public behavior.

PT Tip Top in the "Belajar Sains dirumah Aja" and "Hafalan Doa Harian" 
programs, which he claims is a CSR program, is an application form of the corporate social marketing concept. PT Tip Top carries out corporate branding through a CSR action driven by social media (Instagram) and digital media (zoom), and not merely an attempt to make a social change such as the meaning of the CSR program. As a recommendation, PT Tip Top can make a real social movement action and be carried out regularly. PT Tip Top can support change campaigns on issues of health, poverty, and education by working with communities that focus on social change.

\section{BIBLIOGRAPHY}

Aaker, J., Smith, A., \& Adler, C. (2010). The Dragonfly Effect: Quick, Effective and Powerful Way To Use Social Media, To Drive Social. Jossey-Bass.

Allen, M. (2017). The SAGE Encyclopedia of Communication Research Methods.

https://doi.org/10.4135/97814833814 $11 \mathrm{NV}-4$

AskRoxi. (2014). Personal Values. Leading With Impact: Your Ripple Effect, 29-34.

Brogi, M., \& Lagasio, V. (2019). Environmental, social, and governance and company profitability: Are financial intermediaries different? Corporate Social Responsibility and Environmental Management, 26(3), 576-587. https://doi.org/10.1002/csr.1704

Buckingham, M., \& Coffman, C. (2003). First, Break all the Rules: What the world's greatest managers do differently (Issue 1999, pp. 1-11). Simon \& Schuster.

Chowdhury, R. H., Choi, S., Ennis, S., \& Chung, D. (2019). Which Dimension of Corporate Social Responsibility is

Copyright (C) 2020, FINANCIAL: Jurnal Akuntansi a Value Driver in the Oil and Gas Industry? Canadian Journal of Administrative Sciences / Revue Canadienne Des Sciences de l'Administration, 36(2), 260-272. https://doi.org/10.1002/cjas.1492

Cormode, G., \& Krishnamurthy, B. (2008). Key differences between Web 1.0 and Web 2.0. First Monday, 13(6).

https://doi.org/10.5210/fm.v13i6.212 5

Diener, E. (1984). Subjective well-being. In Psychological Bulletin (Vol. 95, Issue 3, pp. 542-575). American Psychological Association. https://doi.org/10.1037/00332909.95.3.542

Fernández-Guadaño, J., \& Sarria-Pedroza, J. H. (2018). Impact of Corporate Social Responsibility on value creation from a stakeholder perspective. Sustainability (Switzerland), 10(6). https://doi.org/10.3390/su10062062

Fill, C., \& Jamieson, B. (2011). Marketing Communications. Qualitative Market Research: An International Journal, $5(2)$.

https://doi.org/10.1108/qmr.2002.216 05bae.003

Gruen, T. W., Osmonbekov, T., \& Czaplewski, A. J. (2006). eWOM: The impact of customer-to-customer online know-how exchange on customer value and loyalty. Journal of Business Research, 59(4), 449456.

https://doi.org/10.1016/j.jbusres.2005. 10.004

Hanna, R., Rohm, A., \& Crittenden, V. L. (2011). We're all connected: The power of the social media ecosystem. Business Horizons, 54(3), 265-273. https://doi.org/10.1016/j.bushor.2011. 01.007

Hodgetts, D. J., \& Stolte, O. E. E. (2012). Case-based Research in Community and Social Psychology: Introduction 
to the Special Issue. Journal of Community \& Applied Social Psychology, 22(5), 379-389. https://doi.org/10.1002/casp.2124

Kahn, W. A. (2005). Psychological Conditions of Personal Engagement and Disengagement at Work. Langmuir, 21(18), 8250-8254. https://doi.org/10.1021/la051212i

Kahneman, D., Diener, E., \& Schwarz, N. (1999). Well-being: The foundations of hedonic psychology. In Daniel Kahneman, E. Diener, \& N. Schwarz (Eds.), Well-being: The foundations of hedonic psychology. Russell Sage Foundation.

Kahneman, Daniel. (1974). Attention and Effort. In Prentice-Hall (Vol. 14, Issue 6). Prentice-Hall Inc.

Kao, E. H., Yeh, C.-C., Wang, L.-H., \& Fung, H.-G. (2018). The relationship between CSR and performance: Evidence in China. Pacific-Basin Finance Journal, 51, 155-170. https://doi.org/https://doi.org/10.1016 /j.pacfin.2018.04.006

Kietzmann, J. H., Hermkens, K., McCarthy, I. P., \& Silvestre, B. S. (2011). Social media? Get serious! Understanding the functional building blocks of social media. Business Horizons, 54(3), 241-251. https://doi.org/10.1016/j.bushor.2011. 01.005

Kotler, P., \& Lee, N. (2004). Corporate Social Responsibility - Doing the Most Good for Your Company and Your Cause.

Kuppens, P., Realo, A., \& Diener, E. (2008). The Role of Positive and Negative Emotions in Life Satisfaction Judgment Across Nations. Journal of Personality and Social Psychology, 95(1), 66-75. https://doi.org/10.1037/00223514.95.1.66

Lu, J., Ren, L., Lin, W., He, Y., \& Streimikis, J. (2019). Policies to promote corporate social responsibility (CSR) and assessment of CSR impacts. E a M: Ekonomie a Management, 22(1), 82-98. https://doi.org/10.15240/tul/001/2019 -1-006

Marí Farinós, J. (2017). Sustainability as an object of corporate social responsibility . VITRUVIO International Journal of Architectural Technology and Sustainability, Vol 2, No. https://doi.org/10.4995/vitruvioijats.2017.7649

Maslow, A. H. (1968). Toward a psychology of being. D. Van Nostrand Company.

Nawawi. (2003). Metode Penelitian Bidang Sosial. Gadjah Mada University Press.

O'Reilly, T. (2007). What is web 2.0?: Design patterns and business models for the next generation of software. The Social Media Reader, 4580, 3252.

Oishi, S., Diener, E., Suh, E., \& Lucas, R. E. (1999). Value as a Moderator in Subjective Well-Being. Journal of Personality, 67(1), 157-184. https://doi.org/10.1111/14676494.00051

Primahendra, R. (2008). The Secret of CSR: Concept and Application In Bussiness.

Rae, G. (2010). Re-Thinking the Human: Heidegger, Fundamental Ontology, and Humanism. Human Studies, 33(1), 23-39. http://www.jstor.org/stable/40981088

Rahman, R. (2009). Corporate Social Responsibility Antara Teori dan Kenyataan. Buku Kita.

Romli, A. S. (2012). Jurnalistik Online: Panduan Mengelola Media Online. Nuansa Cendikia.

Sammons, A. (2014). The humanistic approach: the basics.

Sawyer, J. E. (1992). Goal and Process Clarity: Specification of Multiple Constructs of Role Ambiguity and a Structural Equation Model of Their 
Antecedents and Consequences. Journal of Applied Psychology, 77(2), $130-142$.

https://doi.org/10.1037/0021-

9010.77.2.130

Shnayder, L., \& Van Rijnsoever, F. J. (2018). How expected outcomes, stakeholders, and institutions influence corporate social responsibility at different levels of large basic needs firms. Business Strategy and the Environment, 27(8), 1689-1707. https://doi.org/10.1002/bse.2235

Solihin, I. (2008). Corporate Social Responsibility from Charity to Sustainability. Four Salemba.

Stake, R. (1995). The art of case research. Sage Publications.

Taliento, M., Favino, C., \& Netti, A. (2019). Impact of environmental, social, and governance information on economic performance: Evidence of a corporate 'sustainability advantage' from Europe. Sustainability (Switzerland), 11(6). https://doi.org/10.3390/su11061738

Thomson, J. (1955). The ethics of Aristotle-The Nicomachean ethics. MD: Penguin.

Tip Top Supermarket. (2020). Instagram Tip Top. https://www.instagram.com/tiptop_id/ Uribe-Macías, M. E., Vargas-Moreno, Ó. A., \& Merchán-Paredes, L. (2017). La responsabilidad social empresarial y la sostenibilidad, criterios habilitantes en la gerencia de proyectos. Entramado, 14(1), 52-63. https://doi.org/10.18041/entramado.2 018v14n1.27107

Vishwakarma, V. (2019). Corporate Social Responsibility (A Literature Review). Shanlax International Journal of Management, 7(1), 36-42. https://doi.org/10.34293/management. v7i1.554

\section{ABOUT THE AUTHORS}

Try Ananto Wicaksono, born in Tangerang, November 10, 1996. He is a Student of a Master's degree in Business Law, Gadjah Mada University (UGM) and a Master's degree in Public Policy, School of Government and Public Policy (SGPP) Indonesia, a former Corporate Social Responsibility (CSR) Representatives for a retail company and Delegate (DKI Jakarta) for Beijing Sister City Youth Camp Program 2019, he has published extensively on International Political Economy (IPE), public policy and foreign policy, as well as on Law. His publications for CSIS Indonesia include "Vietnam's Economic Miracle during COVID-19 Pandemic: What Can Indonesia Learn?" (The Indonesian Quarterly 2020 Vol.48 No.2 Page 100-112, 2020) and "Examining the Policies and Priorities of the Indonesian Government in Response to COVID-19", published in LIPI Center of Political Studies Article Website. 